\title{
SPINAL CORD REGENERATION: THE ACTION OF NEUROTROPHIN-3 IN SPINAL CORD INJURY IN RATS
}

\author{
Douglas Kenji Narazaki, Tarcisio Eloy Pessoa de Barros Filho, Claudia Regina \\ G. C. Mendes de Oliveira, Alexandre Fogaça Cristante, Alexandre Sadao Iutaka, \\ Raphael Martus Marcon, Reginaldo Perilo Oliveira
}

Narazaki DK, de Barros Filho TEP, de Oliveira CRGCM, Cristante AF, Iutaka AS, Marcon R, Oliveira RP. Spinal cord regeneration: the action of neurotrophin-3 in spinal cord injury in rats. CLINICS. 2006;61(5):453-60.

OBJECTIVE: For many years, it was believed that medullary regeneration could not occur, although currently there are many trials using neurotrophic factors, stem cells, fetal medulla grafts, peripheral nerve grafts, and antibodies against myelin-associated proteins that demonstrate the existence of the possibility of spinal cord regeneration. The purpose of this study was to investigate the action of neurotrophin-3, a novel neurotrophic factor.

METHODS: The New York University impactor, a standardized device for delivery of spinal cord injuries was used on 33 rats, which were divided into 2 groups: a control group receiving distilled water intraperitoneally and a treatment group receiving neurotrophin-3 intraperitoneally.

RESULTS: Using the Basso, Beattie, and Bresnahan scale, the locomotor recovery curve for the neurotrophin-3 treated group was superior to that of the control group $(P<0.05)$; the administration of neurotrophin-3 was associated with the absence of deaths, while the control group showed a $28.5 \%(P=0.026)$ mortality rate. Other parameters (hematuria rate and histological analysis) showed no significant differences.

CONCLUSIONS: Based on these results, it appears that a strong relationship exists between the use of neurotrophin-3 in rats with spinal cord injury and better functional recovery.

KEYWORDS: Spinal cord injury. Nerve regeneration. Rats. Neural growth factors.

\section{INTRODUCTION}

For many years, axonal regeneration in the central nervous system has been an objective targeted by many investigators in the medical area. Over the last 2 decades, many approaches have resulted in axonal growth following tissue injuries. Thus, the long-held belief that spinal cord regeneration is unattainable has been refuted. However, it is known that penetrating damage to the spinal cord of mammals results in interruption of both ascending and descending spinal cord pathways. Responses of the body to dam-

Spinal Cord Injury Laboratory, Institute of Orthopedics and Traumatology, Hospital das Clínicas, São Paulo University Medical School - São Paulo/SP, Brazil.

Email: bibgodoi@usp.br

Received for publication on June 02, 2006.

Accepted for publication on June 26, 2006. age include retraction of the proximal stump of the axon, neuronal atrophy, and neuronal death. ${ }^{1}$

Efforts to prevent these sequelae and provide neuronal regeneration arise from the concept of generating an environment suitable for axonal growth in the central nervous system (CNS). Currently, the most investigated approaches are the use of neurotrophic factors for CNS injuries, peripheral or fetal nervous tissue grafts, and antibodies (antimyelin-associated neuronal growth-inhibiting proteins).

Examples of successful trials are the studies of Schnell et al, ${ }^{2}$ Bregman et al, ${ }^{3}$ Cheng et al, ${ }^{4}$ and Grill et al. ${ }^{5}$ Schnell et $\mathrm{al}^{2}$ studied the action of neurotrophic factors, neurotrophin-3 (NT-3), nerve growth factor (NGF), and brain-derived neurotrophic factor (BDNF), on spinal cord injuries in rats following transection of the corticospinal tract. The corticospinal tract plays a major role in nerve 
conduction that determines voluntary motricity in mammals. ${ }^{6}$ These substances were injected into the injury and were shown to be highly effective in axonal regeneration, the most successful one being NT-3.

Neurotrophin-3 is a neurotrophic substance only recently synthesized. This protein belongs to the family of neurotrophins, the amino acid sequence of which is similar in humans, rats, and pigs. Neurotrophin-3 is important for the development and maintenance of the neuronal population, promoting its differentiation. Neurotrophin- 3 is also important for the formation of the substantia nigra and the pyramidal tract that is responsible for motor activity. ${ }^{2}$

Bregman et $\mathrm{al}^{3}$ showed that following damage to the spinal cord of rats, the neutralization by antibodies of myelinderived inhibitors of axonal growth promoted (in the CNS) growth of the cortical spinal, cerulospinal and raphespinal tracts and induced functional recovery of locomotion. The axonal growth distance obtained in this trial was such that it exceeded the injured area; also, the functional recovery of locomotion was so expressive that it almost equalled that of normal uninjured rats in some of the evaluation tests.

Cheng et $\mathrm{al}^{5}$ reported the use of a peripheral nerve bridge inserted into the region of the transected spinal cord of rats and fixed with a mixture of fibrin glue and acidic fibroblast growth factor (aFGF), promoting corticospinal growth and functional recovery of axons.

Grill et $\mathrm{al}^{5}$ grafted transgenically modified cells onto the medullary injury site of rats to release NT-3, obtaining corticospinal axon growth and partial recovery of the axonal function.

Among many neurotrophic factors studied, the one with the best response concerning corticospinal axonal regeneration was NT-3., ${ }^{2,7}$ The studies showed that NT-3 is superior to NGF and BDNF. In addition to the neuronal growth achieved with NT-3, it seems that this substance facilitates the formation of new synapses that are important in neurofunctional recovery. 7,8

\section{OBJECTIVE}

The purpose of this study was to determine whether intraperitoneal administration of NT-3 is a treatment effective to stimulate neural regeneration of spinal cord injury in rats. Both NT-3 and the distilled water placebo were administered intraperitoneally because this route allows quick and complete absorption; moreover it is practical, reproducible, and virtually free of complications when properly handled.

\section{MATERIALS AND METHODS}

Young adult Wistar rats, weighing between 300 and 500 $\mathrm{g}$, were the subjects of our trial. The rats were supplied by the animal house of the Institute of Orthopedics and Traumatology and were accommodated there during the preand postoperative periods. Each cage accommodated 3 rats with free access to water and food; animals were kept warm and were monitored throughout the trial. Ethical standards for use of animals in medical trials were observed, so that the animals were never mistreated or subjected to pain or suffering.

To produce spinal cord injuries in our study, we used a thoroughly tested and recognized apparatus, the New York University (NYU) impactor (Figure 1), a computerized device developed by the New York University and intended to produce an impact using the fall of a weight. ${ }^{9}$ The NYU impactor consists of an interfacing device (instrumentation), PC-compatible IBM microcomputer, VGA monitor, interface plate with parallel exit and timer, and the NYU impactor Software. Basically, this instrument controls and monitors the fall of a rod equipped with a weight targeted to impact the spinal cord. This fall is monitored by multiple sensors connected to a computer that records the weight's height of fall and speed of fall, as well as the instant of impact with the dura mater, the change of position of the spinal cord after the impact, and the spinal cord compression caused by the fall, in addition to identifying errors in the process. Therefore, this medullary injury model, if appropriately used, is practical and reproducible, which is important for injury standardization and investigation.

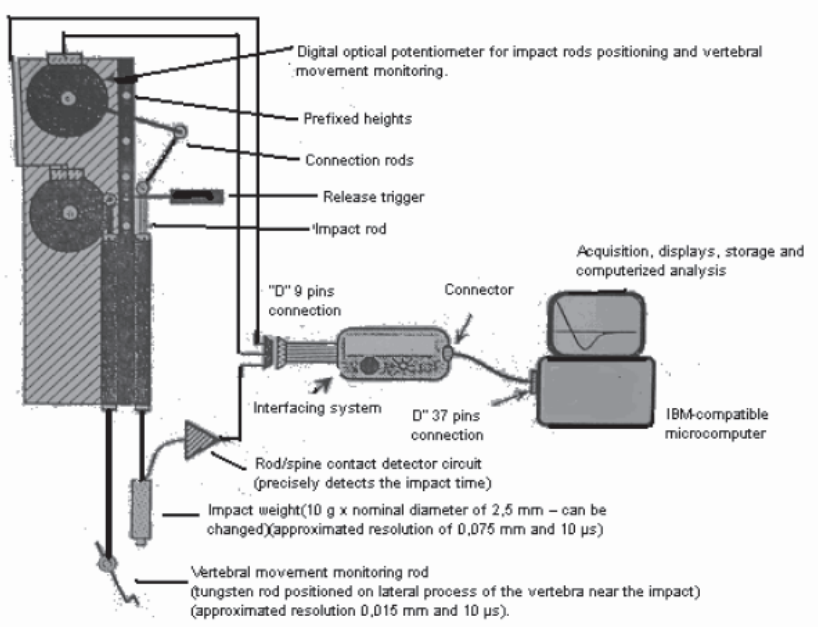

Figure 1 - NYU IMPACTOR

\section{Lesional / management technique}

All rats received sodium pentobarbital anesthesia intraperitoneally ( $40 \mathrm{mg} / \mathrm{kg}$ body weight). After anesthetic induction, animals were tricotomized in the dorsal region and 
positioned on the surgical table. Firstly we made a 4-cm long dorsal median incision in the skin; then we opened the aponeurotic and muscular planes (major muscle dorsal and paravertebral muscle). In this way, we exposed the posterior portion (spinal processes and laminae) of vertebrae $\mathrm{T} 8$, T9, T10, T11, T12, and L1. We then identified the T10 position through tendinous insertion of the major muscle dorsal and rib counting. The spinal process of T9 and T10 was excised using a micropunch, followed by laminectomy at T10 with exposure of the dura mater. An approximately 3$\mathrm{mm}$ long access to the dura mater was formed, enough to accommodate the weight of the NYU impactor. After the laminectomy, we placed the rat on a small pad and fixed the T8 and T11 spinal processes using two clamps fastened to the base of the NYU impactor. We positioned the spine movement sensors over the T9 transverse process and fastened the contact sensor to a structure of the incision. First we placed the weight at height zero in order to achieve correct positioning; then we moved it to the height of fall, standardized at $12.5 \mathrm{~mm}$ for all cases. Then we checked the calibration of all sensors and proceeded with the dropping of the weight. After the free fall, the weight was left to compress the spinal cord for 15 seconds and was then removed. The PC screen was checked for interferences and to make sure everything was in good order.

A total of 33 male Wistar rats were divided into 2 groups following experimental medullary injury: one receiving distilled water (control group) and the other receiving NT-3, $1 \mathrm{mg}$ per rat (treatment group).

The control group included 14 rats weighing between $304 \mathrm{~g}$ and $387 \mathrm{~g}$. In this group, after the spinal cord injury and after the synthesis of the incised planes, $0.4 \mathrm{~mL}$ distilled water was injected intraperitoneally into each rat. The treatment group included 19 rats weighing between $295 \mathrm{~g}$ and $376 \mathrm{~g}$. After the medullary injury and after the synthesis of the incised planes, each rat of the treatment group was injected intraperitoneally with $1 \mathrm{mg}$ of neurotrophin3 diluted in $0.4 \mathrm{~mL}$ of distilled water.

The different number of animals included in the groups (14 vs 19, control vs NT-3 group, respectively) occurred because there was excess study drug and because it was expected that some of the rats in the study might die. Consequently, the number of subjects in the treated group was increased.

After the drug or distilled water was introduced intraperitoneally, we closed the dorsal incision following the incision planes, using 3.0 nylon thread.

\section{Postoperative period}

During the immediate postoperative period, the animals were placed under a heating source, each one in its box, until fully recovered from anesthesia. The heat source was then removed, and food and water were placed inside the boxes, which were then closed. Each rat received cefazolin $(50 \mathrm{mg} / \mathrm{kg} /$ day, intraoperatively and for 10 postoperative days) to prevent infections central nervous system, soft tissue and urinary infections. All rats presenting hematuria were treated with levofloxacin at $7 \mathrm{mg} / \mathrm{kg} / \mathrm{day}$ for 14 days, due to suspicion of urinary infection.

Still aiming at preventing urinary infection, the rats were subjected to bladder compression twice a day during the first 5 days, and then once a day for the next 2 days.

\section{Methods employed to evaluate the results}

Results were analyzed under 4 categories: function, histology, mortality, and frequency of hematuria. Functional and histological results are direct parameters of spinal cord regeneration, while mortality and frequency of hematuria are indirect parameters of spinal cord regeneration.

The functional studies were performed on postoperative days 2, 9, 16, 23, and 30 according to the Basso, Beattie, and Bresnahan (BBB locomotive scoring criteria. ${ }^{10}$ This evaluation was performed in a 1-m diameter circle for 4 minutes for each rat. The range of motion of each joint of the posterior limbs (hips, knees, and ankles), position of the abdomen, body sustentation, position of the posterior paws, balance, locomotion, step coordination, and tail position were evaluated. The rats could be scored from 0 to 21 according to these criteria, where 0 means absence of motility and 21 means normal motility, balance, and coordination. To facilitate the practical and statistical comparisons, the arithmetic mean of the score of right and left posterior limbs was considered for each rat. Only the scores of rats that survived to postoperative day 30 were included. On day 30, all animals were sacrificed for anatomical and pathological evaluation. In this way, the results of 10 control rats were compared with those of 19 rats of the NT-3 group. An overdose of anesthetic pentobarbital (400 mg/ $\mathrm{kg}-10$ times the usual dose) was used, and the spinal cord were removed for histological evaluation. The same, although more extended, laminectomy techniques were used to remove the spinal cord. The anatomical and pathological specimens of spinal cord were preserved in individual jars containing $10 \%$ formalin solution. The injured segment and its cranial and caudal margins were separated from the rest of the specimen. Each segment of the spinal cord was cross-sectioned with a micrometer into thin slices, and each slice was fixed and stained with hematoxylineosin. After this procedure, the nerve tissue was examined under an ordinary optical microscope. 
The histological analysis included both the injury site and its macroscopically intact margins. In this way, it was possible to divide the spinal cord segment into 3 zones: the injury zone, the cranial zone, and the caudal zone. Each was analyzed separately according to anatomical and pathological criteria as follows. These criteria correspond to the following tissue injury stages: hyperemia, cell infiltrate, degeneration of nerve substances, necrosis. The first 3 are considered early responses to an aggressive factor and the last one is the delayed response. Each criterion was scored based on severity, as $0=$ absent, $1=$ mild, $2=$ moderate, and $3=$ intense (Table 1). Finally, these 4 scores were added to obtain a final index (Table 2).

Table 1 - Specific pathoanatomical index

\begin{tabular}{lcccc}
\hline CritERIA & 0 & 1 & 2 & 3 \\
\hline Hyperemia & Absent & Mild & Moderate & Severe \\
Cellular infiltrate & Absent & Mild & Moderate & Severe \\
$\begin{array}{l}\text { Nerve substance } \\
\text { degeneration }\end{array}$ & Absent & Mild & Moderate & Severe \\
Necrosis & Absent & Mild & Moderate & Severe \\
\hline
\end{tabular}

Table 2 - Final pathoanatomical index

\begin{tabular}{ll}
\hline final Score & SEVERITY \\
\hline 0 & No damage \\
$1-4$ & Mild damage \\
$5-8$ & Moderate damage \\
$9-12$ & Severe damage \\
\hline
\end{tabular}

The results obtained by functional and histological studies were analyzed using Windows Excel, Prisma, and Primer software. Excel produced comparative graphs for best data visualization. Prisma and Primer allowed us to perform the statistical study of intergroup differences. We also used the Mann-Whitney and Fisher statistical tests. The Mann-Whitney nonparametric test was chosen because the values found in the study presented non-Gaussian distributions with asymmetry.

\section{RESULTS}

\section{Functional results}

Tables 3 and 4 show the scores for each rat in the weekly evaluations. The average scores of all rats in each group at every weekly evaluation was used for comparisons. Figure 2 shows the comparative analysis of scores versus time. It can be seen that the values of the BBB evaluation curve in group NT-3 was superior to that found in the control group. This difference is statistically significant as shown by the Mann-Whitney test on postoperative days 9, 16, 23, and 30; $(P=0.005,0.0269 ; 0.004$, and 0.004 ,

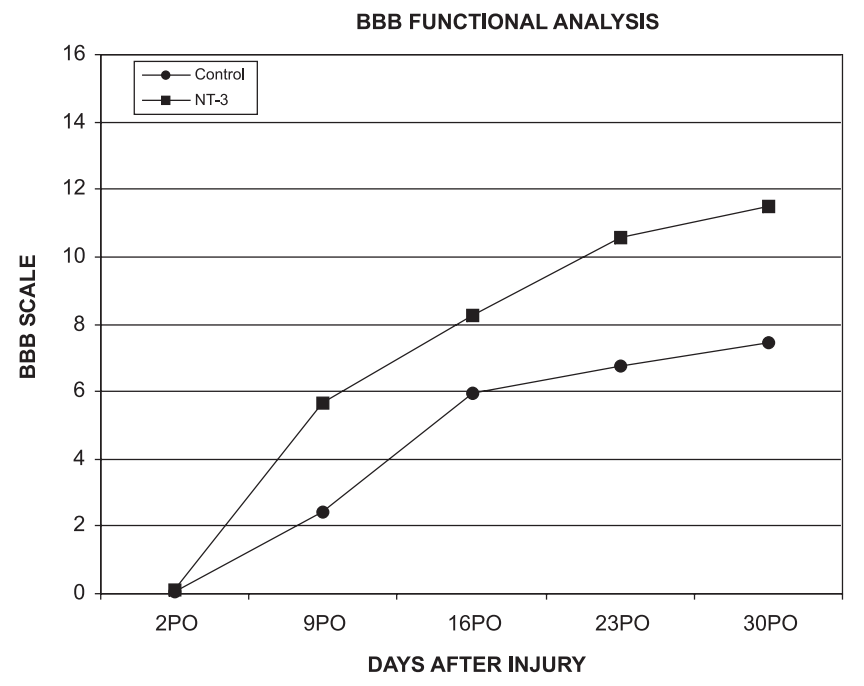

Mann-Whitney Test: $\mathrm{p}\left(2^{\text {nd }} \mathrm{PO}\right)=0.4902$.

$\mathrm{p}\left(9^{\text {th }} \mathrm{PO}\right)=0.0054$.

$\mathrm{p}\left(16^{\text {th }} \mathrm{PO}\right)=0.0269$.

$\mathrm{p}\left(23^{\text {rd }} \mathrm{PO}\right)=0.0044$

$\mathrm{p}\left(30^{\text {th }} \mathrm{PO}\right)=0.0044$.

Figure 2 - Control and NT-3 Groups Functional Analysis

Table 3 - Functional evaluation, control group

\begin{tabular}{|c|c|c|c|c|c|}
\hline RATS & $\begin{array}{c}\text { Postoperative } \\
\text { Day2 }\end{array}$ & $\begin{array}{c}\text { Postoperative } \\
\text { Day } 9\end{array}$ & $\begin{array}{c}\text { Postoperative } \\
\text { Day } 16\end{array}$ & $\begin{array}{c}\text { Postoperative } \\
\text { Day } 23\end{array}$ & $\begin{array}{c}\text { Postoperative } \\
\text { Day } 30\end{array}$ \\
\hline Control 1 & 0 & 0.5 & 3.5 & 3.5 & 6 \\
\hline Control 2 & 0 & 0.5 & 1 & 5 & 4 \\
\hline Control 3 & 0 & 8 & 10 & 10 & 11 \\
\hline Control 5 & 0 & 0 & 1 & 1 & 0.5 \\
\hline Control 6 & 0 & 0.5 & 7 & 9 & 9 \\
\hline Control 7 & 0.5 & 6 & 9 & 10 & 11 \\
\hline Control 8 & 0 & 0 & 5 & 3 & 3 \\
\hline Control 9 & 0 & 1 & 7 & 8 & 9.5 \\
\hline Control 10 & 0 & 7.5 & 8.5 & 10 & 9.5 \\
\hline Control 11 & 0 & 0.5 & 7.5 & 8 & 11 \\
\hline
\end{tabular}


Table 4 - Functional evaluation, NT-3 group

\begin{tabular}{|c|c|c|c|c|c|}
\hline RATS & $\begin{array}{l}\text { Postoperative } \\
\text { Day2 }\end{array}$ & $\begin{array}{c}\text { Postoperative } \\
\text { Day } 9\end{array}$ & $\begin{array}{c}\text { Postoperative } \\
\text { Day } 16\end{array}$ & $\begin{array}{c}\text { Postoperative } \\
\text { Day } 23\end{array}$ & $\begin{array}{c}\text { Postoperative } \\
\text { Day } 30\end{array}$ \\
\hline Treated 1 & 0 & 3.5 & 5 & 8 & 9 \\
\hline Treated 2 & 0 & 3.5 & 4 & 6 & 6 \\
\hline Treated 3 & 0 & 3 & 3 & 7.5 & 7.5 \\
\hline Treated 4 & 0 & 7 & 8 & 12 & 12 \\
\hline Treated 5 & 0 & 7 & 10 & 11 & 11 \\
\hline Treated 6 & 0 & 12 & 12 & 16 & 21 \\
\hline Treated 7 & 0 & 4.5 & 8.5 & 13 & 13 \\
\hline Treated 8 & 0 & 8 & 10 & 13 & 13 \\
\hline Treated 9 & 0.5 & 1 & 7 & 10 & 10 \\
\hline Treated 10 & 0 & 8 & 10 & 11 & 12 \\
\hline Treated 11 & 0 & 2.5 & 8 & 10 & 11 \\
\hline Treated 12 & 0 & 4.5 & 9.5 & 10 & 13 \\
\hline Treated 13 & 0 & 7 & 10 & 10 & 12 \\
\hline Treated 14 & 0 & 2 & 2.5 & 6 & 6 \\
\hline Treated 15 & 0 & 7.5 & 10 & 10 & 12 \\
\hline Treated 16 & 0 & 7 & 9.5 & 9 & 9.5 \\
\hline Treated 17 & 0 & 4 & 7 & 9 & 10 \\
\hline Treated 18 & 2 & 8 & 12 & 17 & 17 \\
\hline Treated 19 & 0 & 8 & 11 & 12 & 13 \\
\hline
\end{tabular}

respectively). Therefore, it can be said that the group receiving intraperitoneal treatment with NT-3 presented improved locomotor recovery when compared with the distilled water placebo treated group.

\section{Histological results}

The comparative analysis used the averages of the final indexes divided by zones (Figure 3 ) and the statistical study used the Mann-Whitney test.

The values of each segment of each rat and each group are shown in Tables 5 and 6. Results show that the NT-3 group presented a lower degree of tissue damage when

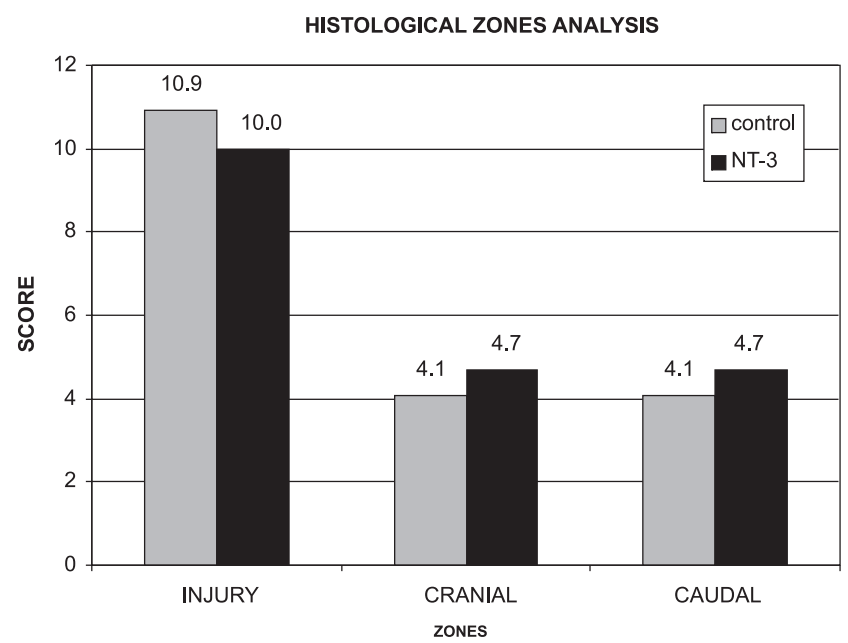

Mann-Whitney Test: $\mathrm{p}$ (injury) $=0,1343 ; \mathrm{p}($ cranial $)=0,13 ; \mathrm{p}($ caudal $)=$ 0,13 .

Figure 3 - Comparative Histological Score Control vs NT-3 Groups
Table 5 - Final histological score, control group

\begin{tabular}{lccc}
\hline RATS & Injury zone & Cranial zone & Caudal zone \\
\hline Control 1 & 12 & 7 & 7 \\
Control 2 & 12 & 10 & 10 \\
Control 3 & 12 & 2 & 2 \\
Control 5 & 12 & 5 & 5 \\
Control 6 & 12 & 2 & 2 \\
Control 7 & 8 & 1 & 1 \\
Control 8 & 10 & 3 & 3 \\
Control 9 & 11 & 2 & 2 \\
Control 10 & 10 & 3 & 3 \\
Control 11 & 10 & 6 & 6 \\
\hline
\end{tabular}

Table 6 - Final histological score, NT-3 group

\begin{tabular}{lccc}
\hline RATS & Injury zone & Cranial zone & Caudal zone \\
\hline Treated 1 & 12 & 5 & 5 \\
Treated 2 & 12 & 7 & 7 \\
Treated 3 & 9 & 5 & 5 \\
Treated 4 & 12 & 5 & 5 \\
Treated 5 & 11 & 5 & 5 \\
Treated 6 & 11 & 4 & 4 \\
Treated 7 & 12 & 4 & 4 \\
Treated 8 & 10 & 4 & 4 \\
Treated 9 & 8 & 6 & 6 \\
Treated 10 & 6 & 5 & 5 \\
Treated 11 & 11 & 4 & 4 \\
Treated 12 & 12 & 5 & 5 \\
Treated 13 & 11 & 6 & 6 \\
Treated 14 & 11 & 4 & 4 \\
Treated 15 & 7 & 3 & 3 \\
Treated 16 & 9 & 4 & 4 \\
Treated 17 & 11 & 6 & 6 \\
Treated 18 & 6 & 5 & 5 \\
Treated 19 & 9 & 2 & 2 \\
\hline
\end{tabular}


compared with the control group at the injury site itself, while the injury extent was greater in the cranial and caudal zones, although these differences were not statistically significant $(P>0.05)$.

Figures 4,5 , and 6 show that in the NT-3 group the delayed response to tissue aggression (necrosis) was notably reduced when compared with the control group in all segments. However, the reduction of acute responses in the NT3 group (hyperemia, inflammation infiltrate, and nerve degeneration) at the injury site was more moderate; these responses were exacerbated in the cranial and caudal zones of the NT-3 group in relation to the control group. The treatment with NT-3 was beneficial, although not statistically significant.

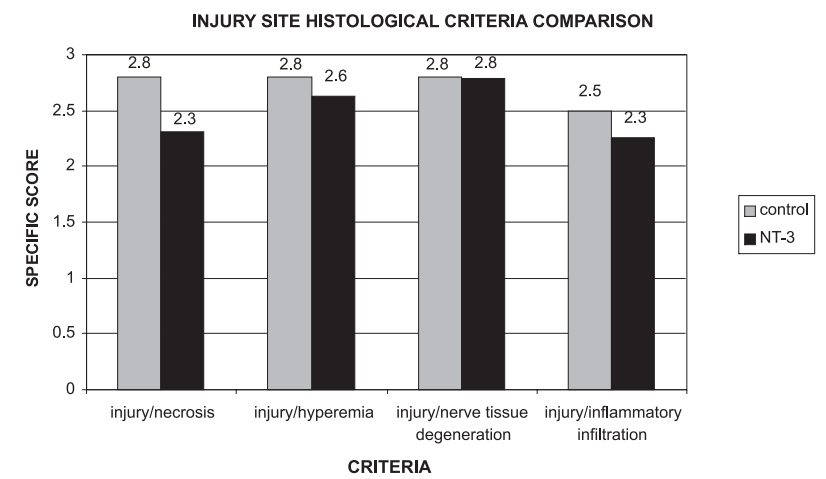

Mann-Whitney Test: $\mathrm{p}$ (necrosis) $=0.0586$

Figure 4 - Comparison of Specific Scores in the Injury Site between Control and NT-3 Groups

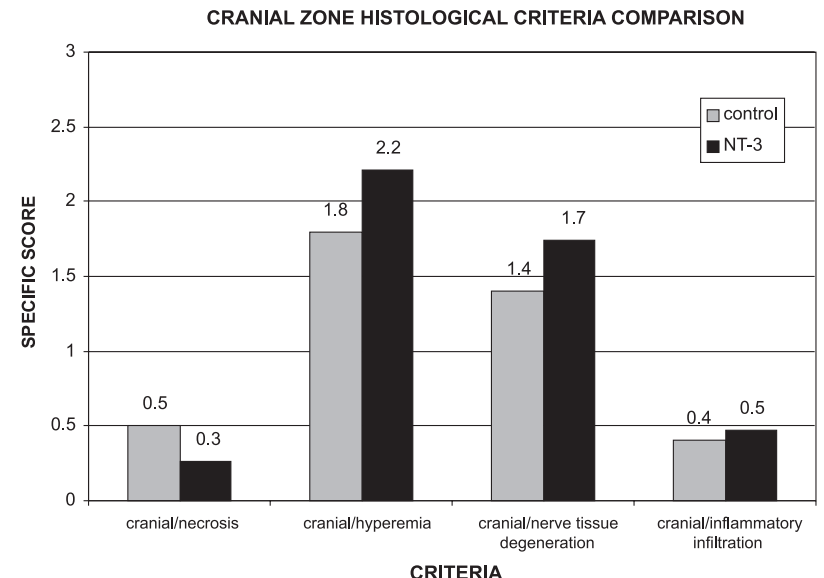

Mann-Whitney Test: $\mathrm{p}$ (necrosis) $=0.3339$.

Figure 5 - Comparison of Specific Scores in the Cranial Zone between Control and NT-3 Groups

\section{Mortality}

There were no deaths in the NT-3 group, whereas in the control group there were 4 deaths $(28,5 \%)$ (Figure 7$)$.

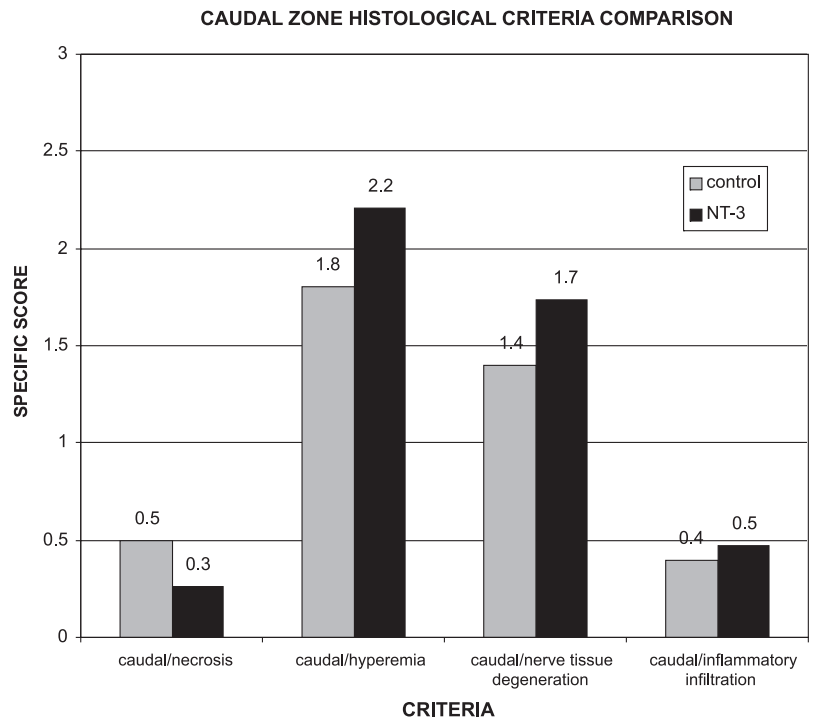

Mann-Whitney Test: $\mathrm{p}$ (necrosis) $=0.3339$.

Figure 6 - Comparison of Specific Scores in the Caudal Zone between Control and NT-3 Groups

This difference was statistically significant $(P=0.024)$. Therefore, it can be said that the treatment with NT-3 was protective in our trial.

DEATHS RATE

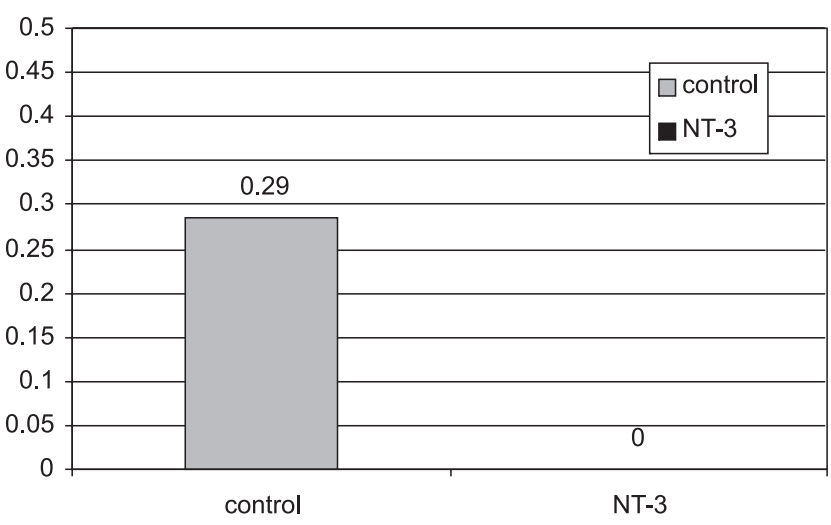

Fisher Test: $\mathrm{p}=0,024$.

Figure 7 - Deaths Rate in Control and NT-3 Groups

\section{Frequency of hematuria}

The frequency of hematuria in the NT-3 group was lower than in the control group (74\% vs $100 \%$, respectively, a difference of $26 \%$ ); however, this difference was not statistically significant $(P=0.057)$ ( Figure 8$)$.

\section{DISCUSSION}

Spinal cord injury in a rat model using the NYU 
HEMATURIA RATES

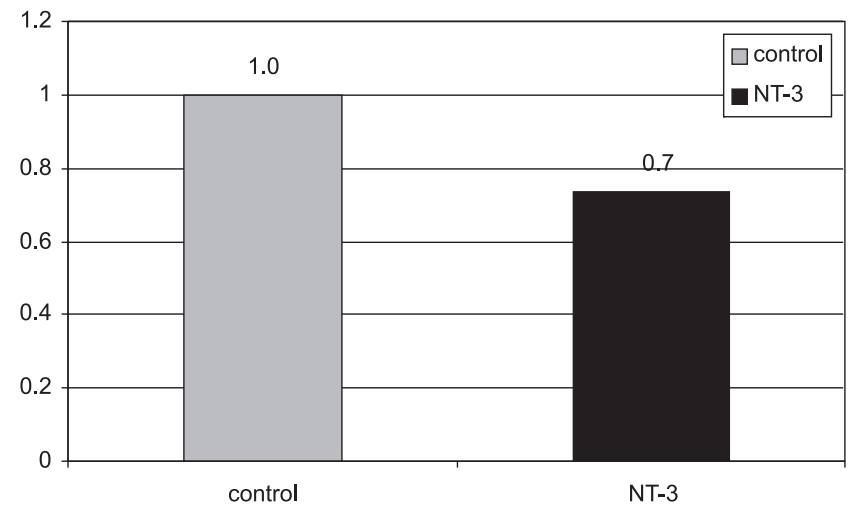

Fisher Test: $\mathrm{p}=0.057$

Figure 8 - Hematuria Rate in Control and NT-3 Groups

impactor was chosen because it determines a standardized neural contusion and is practical, as previously shown. ${ }^{11}$ The BBB locomotor scoring scale was also used because of its wide acceptance in the international literature as a reproducible, practical method of functional analysis. ${ }^{8}$

The benefits provided by intraperitoneal treatment with NT-3 were impressive, as shown by the improved locomotor recovery and reduced mortality. These results were statistically significant.

The benefit as revealed by histology as well as the benefit in terms of renal complications was not statistically significant. Although the benefit concerning renal complications in the treatment group was not statistically significant, it should be noted that there was a $26 \%$ reduction in the incidence of hematuria in that group. Histologically, the NT-3 group showed that the most important action of this drug resides in the reduction of the extent of necrosis, the late, irreversible phase of tissue aggression. The acute phase responses (hyperemia, inflammation, and nerve degeneration) did not improve with this neurotrophic agent. Although not statistically significant, these findings help explain its mechanism of action.

The fact that NT-3 promoted improved motor recovery that was not revealed histologically might have been due to one of the following possibilities: (1) technical limitations of histological analysis using optical microscopy and hematoxylin-eosine staining - the use of immunohistochemical markers would be a more precise manner to evaluate the neural tissue or (2) the short follow-up period (1 month), which may have been insufficient to show identifiable histological changes, since more time might be necessary to observe anatomical and functional agreement. Alternatively, this dissociation might persist regardless of the histological technique or the follow-up period adopted.

Our results are in agreement with previously reported data in terms of the importance of NT-3 in the optimization of neurological recovery of these injured rats. However, the technique that we used to administer the drug (intraperitoneal injection) has advantages over the intrathecal administration used in previous studies ${ }^{1-12}$, being less invasive and more practical.

Further studies are necessary to define the role of neurotrophin-3 as a therapeutical option for patients suffering from radical spinal cord trauma.

\section{RESUMO}

Narazaki DK, de Barros Filho TEP, de Oliveira CRGCM, Cristante AF, Iutaka AS, Marcon R, Oliveira RP. Regeneração medular: a ação do neurotrophin-3 sobre a lesão medular de ratos. CLINICS. 2006;61(5):453-60.

OBJETIVO: Por muitos anos acreditou-se que a regeneração medular não fosse factível. Atualmente porém, existem várias experiências utilizando fatores neurotróficos, células troncos, enxerto de medula fetal, enxerto de nervo periférico e anticorpos contra proteínas associadas a mielina que sugerem o contrário. Esta pesquisa estudou a ação de um dos mais novos neurotróficos, o Neurotrophin-3.

MÉTODOS: As lesões medulares foram realizadas através do New York University impator, método experimental de produção de lesão medular padronizada. Foram utilizados 33 ratos divididos em 2 grupos. Um grupo controle com administração intraperitoneal de água destilada e um gru- po tratamento, tratado com Neurotrophin-3 por via intraperitoneal.

RESULTADOS: Observamos que a curva de recuperação locomotora, segundo a escala de Basso, Beattie e Bresnahan, do grupo Neurotrophin-3 foi superior à do grupo controle ( $\mathrm{p}<0,05$ ); a administração de Neurotrophin-3 determinou ausência de mortes no grupo tratamento, enquanto o grupo controle apresentou taxa de mortalidade de $28,5 \%$ ( $\mathrm{p}=0,026$ ). Os outros parâmetros (taxa de hematúria e análise histológica) não apresentaram diferenças estatisticamente significantes.

CONCLUSÕES: Existe forte relação entre a aplicação de Neurotrophin-3 em ratos com lesão medular e melhor recuperação funcional.

UNITERMOS: Lesões da medula espinhal. Regeneração nervosa. Ratos. Fatores de crescimento neural. 


\section{REFERENCES}

1. Houle JD, Ye JH. Treatment of the chronically injured spinal cord with neurotrophic factors can promote axonal regeneration from supraspinal neurons. Exp Neurol. 1997;143:70-81.

2. Schnell L, Schneider R, Kolbeck R, Barde YA, Schwab ME. Neurotrophin-3 enhances sprouting of corticospinal tract during development and after adult spinal cord lesion. Nature. 1994;7:170-3.

3. Bregman BS, Kunkel-Bagden E, Schnell L, Dai HN, Gao D, Schwab ME. Recovery from spinal cord injury by antibodies to neurite growth inhibitors. Nature. 1995;378:498-501.

4. Cheng H, Yihai C, Olson L. Spinal cord repair in adult paraplegic rats: partial restoration of hind limb function. Science. 1996;273:510-3.

5. Grill R, Murai K, Blesch A, Cage FH, Tuszynski MH. Cellular delivery of neurotrophin-3 promotes corticospinal axonal growth and partial functional recovery after spinal cord injury. J Neurosci. 1997;17:556072.

6. Machado ABM. Neuroanatomia funcional. São Paulo: Atheneu; 1993.

7. Tuszynski MH, Grill R, Blesch A. Spinal cord regeneration. In: Tuszynski MH, Kordower J. editors. CNS Regeneration: basic science and clinical advances. New York: Academic Press; 1999. p. 605-30.
8. Clemente CD. Regeneration in vertebrate central nervous system. Int Rev Neurobiol. 1964;6:257-301.

9. NEW YORK UNIVERSITY, Medical Center. Impactor. NYU Spinal cord contusion system. Operation manual. Impactor software version 7.0. New York, 1993. 41p.

10. Basso DM, Beattie MS, Bresnahan JC. A sensitive and reliable locomotor rating scale for open fields testing in rats. J Neurotrauma. 1995;12:121.

11. Rodrigues NR. Padronização de lesão de medula espinal em ratos Wistar [thesis]. São Paulo: Faculdade de Medicina, Universidade de São Paulo; 1999.

12. Xu XM, Guenard V, Kleitman N, Aebischer P, Bunge MB. A combination of BDNF and NT-3 promotes supraspinal axonal regeneration in Schwann cell grafts in adult rat toracic spinal cord. Exp Neurol. 1995; 134:261-72. 